\title{
RESPIRATORY PROTECTION PROGRAMS (RPP) IMPLEMENTATION AT PRODUCTION UNIT OF A TIN SMELTER AT BANGKA BELITUNG ISLANDS PROVINCE
}

\author{
Maududi Farabi, Mila Tejamaya \\ Department of Occupational Health and Safety, Public Health Faculty, University of Indonesia \\ Kampus Baru UI Depok - West Java 16424, Indonesia
}

\begin{abstract}
The fume generated from the reaction of flux and molten tin produces tin compounds in the atmosphere which potentially lead to stannosis or also known as tin pneumoconiosis after chronic inhalation and prolonged exposure in the workplaces e.g. in smelter industries. The risk can be minimized by implementing Respiratory Protection Program (RPP).This study aimed to evaluate the implementation of RPP at one smelter industry in Bangka Belitung Province. This was an evaluation study that qualitatively evaluated the implementation of RPP. Eigth RPP elements from National safety Council (NSC) Australia was used as guideline. The secondary data from Occupational Health and Safety inspection and monitoring report at one of tin smelter from Department of Manpower (Disnaker), Bangka Belitung Island province. It was found that several RPP elements have not been fully implemented, which were compliance with respirator standards, no selection of respirators procedure, no protective clothing, no fit testing execution, improper management of cleaning and inspections, and no evaluation of respirator usage. Moreover, the specific work process that need Supplied Air Respirator (SAR) has not been anticipated, and improvement in the training materials, periodic training schedule and evaluation of the Respiratory Protection Program were emphasized.There were three informants in this study consisting of company managers, safety officers, and labor inspectors. The implementation of RPP at PT X. Tin needs to be enhanced. Continuous coaching, monitoring, inspection, and evaluation related to the Respiratory Protection Program must be carried out more intensively both internally and externally from the government.
\end{abstract}

Keywords: Respiratory Protection Program (RPP), tin smelter, stannosis

\begin{abstract}
ABSTRAK
Asap yang dihasilkan dari reaksi flux dan lelehan timah dapat menghasilkan senyawa timah di atmosfir yang berpotensi untuk menimbulkan stannosis atau disebut juga tin pneumoconiosis setelah terhirup secara kronis dan terpapar dalam waktu lama misalnya di industri smelter. Risiko tersebut dapat diminimalisir dengan menerapkan Respiratory Protection Program (RPP). Penelitian ini bertujuan untuk mengevaluasi penerapan RPP pada salah satu pabrik peleburan di Provinsi Kepulauan Bangka Belitung. Penelitian ini merupakan evaluation study yang mengevaluasi secara kualitatif penerapan RPP. Delapan elemen RPP dari National Safety Council (NSC) Australia digunakan sebagai pedoman. Penelitian ini menggunakan data sekunder dari hasil pemeriksaan dan inspeksi K3 pada salah satu pabrik peleburan timah dari Dinas Tenaga Kerja Provinsi Kepulauan Bangka Belitung. Informan pada penelitian ini terdiri dari 3 pihak, yaitu: pengurus perusahaan, petugas K3, dan pengawas ketenagakerjaan. Diketahui bahwa beberapa elemen RPP yang belum sepenuhnya dilaksanakan, yaitu: kepatuhan terhadap standar respirator, tidak adanya prosedur pemilihan respirator, tidak adanya pakaian pelindung, tidak adanya pelaksanaan uji kesesuaian, manajemen pembersihan dan inspeksi yang tidak tepat, dan tidak ada evaluasi penggunaan respirator. Selain itu, proses kerja spesifik yang membutuhkan Supplied Air Respirator (SAR) belum diantisipasi, peningkatan materi pelatihan, jadwal pelatihan berkala dan evaluasi RPP perlu diperhatikan. Penerapan RPP di pabrik peleburan timah PT. X perlu ditingkatkan, Pembinaan, pengawasan, pemeriksaandan evaluasi secara terus menerus terkait Respiratory Protection Program harus dilakukan lebih intensif dilakukan baik secara internal maupun eksternal dari pemerintah.
\end{abstract}

Kata Kunci: Respiratory Protection Program (RPP), tin smelter, stannosis

Correspondece Address: Mila Tejamaya, Departement of Occupational Health and Safety, Public Health Faculty, University of Indonesia Kampus Baru UI Depok - West Java 16424, Indonesia, E-mail : tejamaya@ui.ac.id 


\section{Introduction}

The respiratory is the most important route of entry for airborne hazardous substances. ${ }^{1}$ Respiratory hazards or risk factors at the workplace can be generated from raw materials, byproducts, production processes, products or waste. Respiratory Hazards can be in the form of dust / particulate, gas, vapor or fume, in the form of organic or inorganic materials. ${ }^{2}$ Occupational lung diseases or occupational respiratory disorders or occupational respiratory diseases is a disease that is often found in the workplace. Each year, there are approximately 12,000 deaths from lung disease related to workplace exposures. An estimated 20,000 new reported cases of lung disease were caused or exacerbated by work. ${ }^{1}$ Percentage of occupational lung disease contributing to estimated mortality annually ${ }^{3}$ : (1) Chronic Obstructive Pulmonary Diseases (COPD), 32\%; (2) Non-asbestos related lung cancer, 22\% (3) Mesothelioma, 20\% (4) Asbestos related lung cancer, $20 \%$ (5) Other diseases, 5\%. Occupational respiratory diseases onset depends on the agents to which the worker is exposed, including inert or non-fibrogenic dust, dust, fibrogenic, chemical irritants. ${ }^{4}$ The Indonesian government, through Presidential Regulation No. 7 of 2019, determines that lung disease that results from a factor arising from work activities is classified as occupational disease. ${ }^{5}$

Indonesian tin deposits are among the richest tin routes in the world. ${ }^{6}$ The Bangka Belitung Islands are one of the second largest tin producers in the world after China. Tin smelters melt tin concentrate into tin metal. ${ }^{7}$ Tin smelters' workers with prolonged exposure to Tin oxide dust can develop pneumoconiosis. Stannosis is a type of pneumoconiosis caused by inhalation of lead in the form of tin oxide $\left(\mathrm{SnO}_{2}\right)$ smoke or dust. ${ }^{8}$ Stannosis or also known as tin pneumoconiosis is a non fibrotic pneumoconiosis that occurs after chronic inhalation or heavy and prolonged exposure to tin oxide particles. The fume arising from the reaction of flux and molten tin produces tin compounds in the atmosphere. This is the mechanism by which labor exposure to lead may result in stannosis. ${ }^{9}$

Based on an investigation report by the Malaysian federation, 12 cases of stannosis were found from medical examinations of workers from tin smelters. The results of the investigation show that stannosis occurred in the mixing chamber of 1 case, 6 cases in the furnace department and 5 cases in the tin bag department. ${ }^{10}$ The working conditions and incidence of stannosis from the tin smelting plant have also been reported based on clinical symptoms and radiographs of a total of 117 cases of stannosis at Kunming Metallurgical Disease Hospital, Renmin-dong Rd., Kunming, China. It is believed that stannosis is a non-fibrogenic metal dust pneumoconiosis. ${ }^{11}$ Occupational respiratory disease can arise with various symptoms from mild coughing to serious shortness of breath. Companies can suffer losses due to decreased worker productivity and even risk losing reliable workers. ${ }^{2}$ 
Workers exposed to various respiratory hazards, require the use of respiratory protective equipment and the application of the Respiratory Protection Program (RPP) ${ }^{12}$. Respiratorscan be the last line of defense for workers for protection from dust and fiber, smoke, fog, gases, vapors, and biological hazards. ${ }^{13}$ The Respiratory Health Protection Program Respiratory Protection Program is used to ensure that respiratory protection equipment (RPE) is properly selected, used and cared for. RPP is a comprehensive and multidisciplinary program with the aim of reducing the incidence of lung disease in the workplace and preventing direct and indirect harm caused by occupational respiratory disease. ${ }^{1}$ RPP must be implemented in an integrated manner with Occupational Health and Safety. ${ }^{14}$

This research is related to the implementation of the Respiratory Protection Programs (RPP) at production unit of a tin smelter at Province of Bangka Belitung Islands. The purpose of this study was to determine Occupational Health Risks and Similar Exposure Group (SEG), identify respiratory hazards and the application of the Respiratory Protection Program (RPP).

\section{Method}

This research was an evaluation study that qualitatively evaluate the implementation of RPP. This study aimed to evaluate the implementation of RPP at production unit of a tin smelter Province of Bangka Belitung Islands and was carried out from June to September 2020. Eight elements of the RPP from the Australian National Safety Council (NSC) are used as guidelines, consists of: (1) Selection of proper respiratory protective equipment, (2) Medical evaluation procedure, (3) Fit testing procedure, (4) Proper respirator use, (5) Cleaning, disinfecting, storing, inspecting, repairing and discarding, (6) Procedures to ensure adequate air quality, quantity and flow of breathing air for SAR (Supplied Air Respirator), (7) Training, (8) Program Evaluation. This study used secondary data from the results of the OHSs' coaching and inspection at production unit of a tin smelter from Manpower Departments' Bangka Belitung Islands Province. The informants in this study consisted of 3 parties, that was company management, OHS officers, and labor inspectors. RPP elements compliance assessed by number of production units which is implement the RPP, that is: furnaces, warehouses, laboratories, and workshops. The application assessment is carried out based on the results of interviews, document checking and field observations.

\section{Results}

Tin Smelter PT. X is engaged in the processing industry business sector, that is processing tin ore to be smelted into semi-finished goods in the form of tin blocks with controlled tin content to suit trade requirements. Based table 1, there were 90 workers in the furnace and warehouse areas whose main activities are operating productions' equipment for furnaces' type, pouring tin liquid into tin block molds, and carrying out handling using forklifts and transport aircraft. Potential 
hazards for workers in the furnace and warehouse areas include furnace smoke, anthracite, tins' sand, $\mathrm{CaCO}_{3}$, sulfur, machine noise, temperature, overwork, $\mathrm{CO}$, engine exhaust, lead, electricity, dust, vibration, awkward posture, and UV light radiation. The laboratory area consists of 8 workers with activities to analyze the quality of raw materials and production results. Potential hazards from using chemicals in laboratory areas include hydrochloride acid, sodium chloride, aluminium, caustic soda, alcohol 90\%. In the workshop, generator and compressor area there were 8 workers who responsible for operating production equipments consists of welding machines, lathes, grinders, generators, pressure vessel for compressors' air receiver tank types, as well as various maintenance and repair functions, especially electrical installations in the workplace. Potential hazards in the workshop area, generators and compressors include welding fumes, noise, hot temperature, overload, engine exhaust, cadmium, lead, NO2, awkward posture, and electrical. The following is a brief description table of occupational health risk factors in the production unit a Tin Smelter:

Table 1. Area, Number of Workers, and Health Hazard Identificationat a Tin Smelter

\begin{tabular}{|c|c|c|c|}
\hline Area & $\begin{array}{c}\text { Number of } \\
\text { Workers }\end{array}$ & Activities & Potential Hazards \\
\hline $\begin{array}{l}\text { Furnaceand } \\
\text { Warehouse }\end{array}$ & 90 peoples & $\begin{array}{l}\text { Furnace operation, tin block } \\
\text { moldings, forklift; }\end{array}$ & $\begin{array}{l}\text { Furnace smoke, antrasit, } \\
\text { tins' sand, } \mathrm{CaCO}_{3} \text {, sulfur, } \\
\text { machine noise, temperature, } \\
\text { overwork, } \mathrm{CO} \text {, engine } \\
\text { exhaust, lead, electricity, } \\
\text { dust, vibration, awkward } \\
\text { posture, UV light radiation }\end{array}$ \\
\hline Laboratory & 8 peoples & $\begin{array}{l}\text { Perform quality analysis of the } \\
\text { quality of raw materials and } \\
\text { production results }\end{array}$ & $\begin{array}{l}\mathrm{HCl}, \mathrm{NaCl} \text {, aluminium, } \\
\text { caustic soda, alcohol } 90 \% \text {, } \\
\text { air quality, floor } \\
\text { cleaner }\end{array}$ \\
\hline $\begin{array}{l}\text { Workshop, } \\
\text { genset, and } \\
\text { Compressor }\end{array}$ & 8 peoples & $\begin{array}{l}\text { Operate welding machines, lathes, } \\
\text { grinders, generators, compressors, } \\
\text { repair electrical installations and } \\
\text { other equipments }\end{array}$ & $\begin{array}{l}\text { Welding fumes, noise, hot } \\
\text { temperature, overload, } \\
\text { engine exhaust, cadmium, } \\
\text { lead, } \mathrm{NO}_{2} \text {, awkward } \\
\text { posture, electrical }\end{array}$ \\
\hline
\end{tabular}

PT. X Tin Smelter operations for 24 (twenty-four) hours, divided into 3 (three) shifts per day. The total number of workers at Tin Smelter PT. X is 130 people. The main parts of production unit of tin smelter PT. X consists of: the furnace and warehouse area, workshop area, generator and compressor area, and laboratory area.

The following table 2 is a Health Risk Assessment related to occupational diseases at production unit of PT. X tin Smelter. The standard risk analysis used is HB 346 : Risk Management Guidelines Companion to AS/NZS 4360 : 2004, Standard Australia International Ltd. ${ }^{15}$ Occupational health and safety risk analysis uses the semi quantitative method. ${ }^{16}$ 
Table 2. Health Risk Assessment at Production Unit of PT. X Tin Smelter

\begin{tabular}{|c|c|c|c|c|c|c|c|c|c|c|c|c|c|}
\hline \multicolumn{2}{|c|}{ No.: HRA - 07} & \multicolumn{3}{|l|}{ Rev.\#: 3} & \multicolumn{4}{|c|}{ Health Risk Assessment (HRA) } & \multicolumn{5}{|c|}{ Page: 1} \\
\hline \multicolumn{14}{|c|}{ Location: Tin Smelter PT. X Furnace Area, Workshop, Laboratory and genset room } \\
\hline \multicolumn{14}{|c|}{ Job / Equipment / Process Description: Smelter Operation } \\
\hline \multirow[t]{2}{*}{ No } & \multirow[t]{2}{*}{ SEG } & \multicolumn{2}{|c|}{ Risk Identification } & \multirow{2}{*}{$\begin{array}{c}\text { Risk } \\
\text { Control } \\
\text { (Existing) }\end{array}$} & \multicolumn{4}{|c|}{ Risk Assessment } & \multirow{2}{*}{$\begin{array}{c}\text { Risk Control } \\
\text { (Recommended) }\end{array}$} & \multicolumn{4}{|c|}{ Residual Risk } \\
\hline & & Hazard & Risk & & $\mathbf{C}$ & $\mathbf{E}$ & $\mathbf{L}$ & Level of Risk & & $\mathbf{C}$ & $\mathbf{E}$ & $\mathbf{L}$ & Level of Risk \\
\hline 1. & $\begin{array}{l}\text { Electrical } \\
\text { furnace } \\
\text { operators, Lori } \\
\text { operators, crane } \\
\text { operators, forklift } \\
\text { driver, } \\
\text { warehouse } \\
\text { operator }\end{array}$ & $\begin{array}{l}\text { Antrasit, tins' } \\
\text { sand, } \mathrm{CaCO}_{3} \text {, } \\
\text { sulfur, machine } \\
\text { noise, } \\
\text { temperature, } \\
\text { overwork, CO, } \\
\text { engine exhaust, } \\
\text { lead, electricity, } \\
\text { dust, vibration, } \\
\text { awkward } \\
\text { posture, UV rays }\end{array}$ & $\begin{array}{l}\text { Stannosis, NIHL, heat } \\
\text { rash, heat cramp, heat } \\
\text { exhaustion, heat stroke, } \\
\text { stress, CVD, Sirosis, } \\
\text { Glomerulonefritis, } \\
\text { refluks netropati, } \\
\text { Pneumokoniosis, } \\
\text { bronkitis, LBP, cataract }\end{array}$ & $\begin{array}{l}\text { Masker, } \\
\text { Earplug, }\end{array}$ & 25 & 10 & 6 & $\begin{array}{c}1500 \\
\text { (Very High) }\end{array}$ & $\begin{array}{l}\text { Exhaust ventilation, } \\
\text { machine / operator } \\
\text { isolation, SOP, PPE, } \\
\text { work evironment } \\
\text { measurement and } \\
\text { control, wet work } \\
\text { processes, drinking } \\
\text { adequate water, adequate } \\
\text { rest, education, RPP }\end{array}$ & 5 & 1 & 1 & $\begin{array}{c}\mathbf{5} \\
\text { (Acceptable) }\end{array}$ \\
\hline 2. & $\begin{array}{l}\text { Laboratory staff, } \\
\text { cleaning service }\end{array}$ & $\begin{array}{l}\mathrm{HCl}, \mathrm{NaCl} \text {, } \\
\text { aluminium, } \\
\text { caustic soda, } \\
\text { alcohol } 90 \% \text {, air } \\
\text { quality, floor } \\
\text { cleaner }\end{array}$ & $\begin{array}{l}\text { Sirosis, cancer, } \\
\text { glomerulonefritis, } \\
\text { refluks netropati, } \\
\text { dermatitis, respiratory } \\
\text { tract irritation }\end{array}$ & $\begin{array}{l}\text { Laborator } \\
\text { y coat, } \\
\text { masker }\end{array}$ & 25 & 10 & 3 & $\begin{array}{c}\mathbf{7 5 0} \\
\text { (Very High) }\end{array}$ & $\begin{array}{l}\text { Hazard elimination, } \\
\text { exhaust ventilation, } \\
\text { work permit, healthy } \\
\text { life, PPE (mask + gloves } \\
\text { + apron), work } \\
\text { evironment } \\
\text { measurement and } \\
\text { control, education, RPP }\end{array}$ & 5 & 0,5 & 1 & $\begin{array}{c}\mathbf{0 , 2 5} \\
\text { (Acceptable) }\end{array}$ \\
\hline 3. & $\begin{array}{l}\text { Maintenance } \\
\text { technician, } \\
\text { workshop } \\
\text { operators, } \\
\text { compressor } \\
\text { andgenset } \\
\text { operators }\end{array}$ & $\begin{array}{l}\text { Welding fumes, } \\
\text { noise, hot } \\
\text { temperature, } \\
\text { overload, engine } \\
\text { exhaust, } \\
\text { cadmium, lead, } \\
\mathrm{NO}_{2} \text {, awkward } \\
\text { posture }\end{array}$ & $\begin{array}{l}\text { NIHL, heat rash, heat } \\
\text { cramp, heat exhaustion, } \\
\text { heat stroke, stress, CVD } \\
\text { Glomerulonefritis, } \\
\text { refluks netropati, } \\
\text { bronchitis, } \\
\text { Pneumokoniosi, LBP }\end{array}$ & $\begin{array}{l}\text { Earplug, } \\
\text { masker }\end{array}$ & 25 & 6 & 3 & $\begin{array}{c}\mathbf{4 5 0} \\
\text { (Very High) }\end{array}$ & $\begin{array}{l}\text { Exhaust ventilation, } \\
\text { machine / operator } \\
\text { isolation, SOP, PPE, } \\
\text { work evironment } \\
\text { measurement and } \\
\text { control, drinking } \\
\text { adequate water, adequate } \\
\text { rest, education, RPP }\end{array}$ & 5 & 0,5 & 1 & $\begin{array}{c}\mathbf{0 , 2 5} \\
\text { (Acceptable) }\end{array}$ \\
\hline \multicolumn{9}{|c|}{ Assessed by: OHS Officer, Production Head, Production Foreman } & Date: 09 June 2020 & & & & \\
\hline Name & & & Unit & Sign & \multirow{2}{*}{\multicolumn{4}{|c|}{ Checked by: Safety Manager }} & Sign: & & & & \\
\hline OHS & & & OHS & Sign & & & & & Sign & & & & \\
\hline Head & & & Production & Sign & \multirow{2}{*}{\multicolumn{4}{|c|}{ Approved by: Director }} & Sign: & & & & \\
\hline Forem & & & Production & Sign & & & & & Sign & & & & \\
\hline
\end{tabular}

252 November 2020 
Based on Health Risk Assessment result above and hazard mapping, the following table describes the Similar Exposure Group (SEG) at the a tin smelter. Table 3 describes the health risks and groups of workers affected by the tin smelter based on the types of occupational health hazards consisting of dust, chemicals, radiation, work posture, working temperature, and psychosocial hazards. Workers in furnaces, warehouses, laboratories and workshops are SEGs who can be exposed to all types of identified health hazards. SEG workers in the furnace consists of operators of furnaces, lorries, and cranes. SEG for warehouse workers consists of warehouse operators and forklift operators. SEG for laboratory workers consists of analysts and waste officers. SEG for workshop workers consists of technicians, workshop operators and generator operators. Health problems that have the potential to occur in workers in tin smelters include: stannosis, pneumoconiosis, bronchitis, respiratory tract irritation, cirrhosis, reflux netrophaty, cataracts, musculoskeletal disorder, heat stroke, cancer, infectious diseases, sick building syndrome, asthma, work stress, disorders. mental, and cardiovascular diseases.

Table 3. Similar Exposure Group (SEG) from Health Risk Assessmentat Production Unit Tin Smelter

\begin{tabular}{|c|c|c|c|c|}
\hline \multirow{2}{*}{ Types of Hazard } & \multicolumn{3}{|c|}{ Similar Exposure Group (SEG) } & \multirow{2}{*}{ Health Risk } \\
\hline & Location & Worker & Position & \\
\hline \multirow[t]{4}{*}{$\begin{array}{l}\text { Dust, smoke, welding fume, enginee } \\
\text { exhaust andindoor air quality }\end{array}$} & Furnace & 60 & Furnace, lori, crane operators & Stannosis, pneumokoniosis, \\
\hline & Warehouse & 30 & Warehouse, forklift operators & Bronkitis, respiratory \\
\hline & Laboratory & 8 & Laboratory staff, cleaning service & tract irritation, \\
\hline & Workshop & 8 & Maintenance technician, operators & \\
\hline Chemical ( $\mathrm{HCl}, \mathrm{NaCl}$, & Furnace & 60 & Furnace, lori, crane operators & Sirosis, cancer, \\
\hline sulfur, $\mathrm{CaCO}_{3}$, antrasit, tins' sand & Warehouse & 30 & Warehouse, forklift operators & dermatitis, \\
\hline aluminium, caustic soda, alcohol & Laboratory & 8 & Laboratory staff, cleaning service & dlomerulonefritis, \\
\hline floor cleaner) & Workshop & 8 & Maintenance technician, operators & refluks netropati, \\
\hline UV radiation & Furnace & 60 & Furnace operator & Cataract, skin cancer \\
\hline Ergonomics & Furnace & 60 & Furnace, lori, crane operators & Low back pain, \\
\hline (awkward work posture, manual & Warehouse & 30 & Warehouse, forklift operators & Musculosceletal Disorders \\
\hline \multirow[t]{2}{*}{ handling) } & Laboratory & 8 & Laboratory staff, cleaning service & \\
\hline & Workshop & 8 & Maintenance technician, operators & \\
\hline \multirow[t]{3}{*}{ Extreme working temperature } & Furnace & 60 & Furnace, lori, crane operators & Heat rash, heat cramp, \\
\hline & Warehouse & 30 & Warehouse, forklift operators & Heat exhaustion, heat stroke \\
\hline & Workshop & 8 & Maintenance technician, operators & other kidney disorders \\
\hline Biological & All area & 130 & All position & Infectious diseases \\
\hline Psychosocial & All Area & 130 & All position & Fatigue, mental dis., stress, CVD \\
\hline
\end{tabular}


Table 4 describes dust, welding fume, engine exhaust, air quality, and chemical as occupational respiratory hazards that have the potential to have an impact on workers' breathing. The risks of occupational respiratory diseases include stannosis, pneumoconiosis, bronchitis, respiratory tract irritation, sick building syndrome, and asthma. The use of respiratory PPE is especially required for workers in furnaces, warehouses, laboratories and workshops related to the dangers of dust, welding fume, engine exhaust, and chemicals.

Respiratory Protection Program (RPP) implementation At production Unit PT. X Tin Smelter based on national Safety Council (NSC) year of 2002 is summarized in the following table. Numbers 1 (one) to 4 (four) indicate the number of production units at PT. X which is required to implement the Respiratory Protection Program (RPP), namely: furnaces, warehouses, laboratories, and workshops. The application assessment is carried out based on the results of interviews, document checking and field observations.

Table 4. Respiratory Hazard at Production Unit PT X Tin Smelter

\begin{tabular}{|c|c|c|c|c|}
\hline \multirow{2}{*}{ Types of Hazard } & \multicolumn{3}{|c|}{ Similar Exposure Group (SEG) } & \multirow{2}{*}{ Occupational Diseases Risk } \\
\hline & Location & Worker & Position & \\
\hline \multirow{4}{*}{$\begin{array}{l}\text { Dust, smoke, welding fume, enginee } \\
\text { exhaust, and indoor air quality }\end{array}$} & Furnace & 60 & Furnace, lori, crane operators & Stannosis, pneumokoniosis, \\
\hline & Warehouse & 30 & Warehouse, forklift operators & bronkitis, respiratory \\
\hline & Laboratory & 8 & Laboratory staff, cleaning service & tract irritation, Sick Building \\
\hline & Workshop & 8 & Maintenance technician, operators & Sydrome, asthma, \\
\hline \multirow{4}{*}{$\begin{array}{l}\text { Chemical }(\mathrm{HCl}, \mathrm{NaOH} \text {, } \\
\text { sulfur, } \mathrm{CaCO}_{3} \text {, antrasit, tins' sand } \\
\text { aluminium, caustic soda, alcohol } \\
\text { floor cleaner) }\end{array}$} & Furnace & 60 & Furnace, lori, crane operators & \\
\hline & Warehouse & 30 & Warehouse, forklift operators & \\
\hline & Laboratory & 8 & Laboratory staff, cleaning service & \\
\hline & Workshop & 8 & Maintenance technician, operators & \\
\hline
\end{tabular}

Based on table 5, several criteria for the National Safety Council (NSC) Respiratory Protection Program (RPP) have not been fulfilled yet at unit production PT. X tin smelter, consists of: (1) The masks used only meet the Indonesian National Standard (SNI), while the RPP requirements for PPE selected must meet the National Institute for Occupational Safety and Health (NIOSH) standards; (2) The selection of respiratory PPE has not been carried out prior exposure assessment, without considering its relevance to workplace conditions, and has not yet considered the user factor; (3) Workers in the furnace, warehouse and workshop are not equipped with special protective clothing related to the hot working environment and excessive physical workload; (4) The fit testing procedure has not been prepared and all criteria (sub elements) related to the fit testing procedure for the Respiratory Protection Program (RPP) have not been implemented; (5) PPE for workers in the furnace and workshops has not paid attention to factors related to contaminants, occupation, and users; (6) Each worker is provided with respiratory PPE, thereby minimizing use by different individuals. However, there is no mechanism for suppressing and 
monitoring the cleaning of respiratory PPE that is provided. In a sense, cleaning is given the responsibility of each user to manage and maintain it; (7) The laboratory and workshop areas are not yet equipped with special respiratory PPE related to emergencies; (8) PPE given to workers has never been inspected and repaired in accordance with the standard elements in the Respiratory Protection Program; (9) Special places for storage of respiratory PPE have been provided for furnace and laboratory areas. However, in the warehouse and workshop area, there is no special storage container for respiratory PPE provided; (10) Supplied Air Respirator (SAR) is available in the furnace and workshop areas, while laboratory and warehouse areas are assessed to be able to use from the available areas; (11) The available Supplied Air Respirator (SAR) standards are still in accordance with the manufacturer's standards and are used, among others, for confined spaces; (13) Training related to the use of Personal Protective Equipment (PPE) including respiratory PPE has been carried out for all workers when they are first hired to work. However, the training material had not touched yet to the medical symptoms of respiratory PPE using and the general requirements for Occupational Safety and Health Administration (OSHA) for a respiratory protection standards; (14) Periodic training related to the use of respiratory PPE and other has not been programmed yet; (15) Evaluation of the Respiratory Protection Program has not been carried out.

Table 5. Respiratory Protection Program Implementation at Production Unit PT. X Tin Smelter

\begin{tabular}{|c|c|c|c|c|}
\hline Elements \& Sub & $\begin{array}{c}\text { Not } \\
\text { implemented }\end{array}$ & $\begin{array}{c}\text { Partially } \\
\text { implemented }\end{array}$ & $\begin{array}{c}\text { Fully } \\
\text { implemented }\end{array}$ & $\begin{array}{c}\text { Not } \\
\text { applicable }\end{array}$ \\
\hline \multicolumn{5}{|l|}{$\begin{array}{l}\text { Element 1: Selection of proper respiratory protective } \\
\text { equipment }\end{array}$} \\
\hline A respirator must be NIOSH approved & 4 & - & - & - \\
\hline \multicolumn{5}{|l|}{ Respirator selection must be based on: } \\
\hline 1) The hazard to which the worker is exposed; & - & 4 & - & - \\
\hline 2) Exposure assessment; & 4 & - & - & - \\
\hline 3) Relevant workplace; & 4 & - & - & - \\
\hline 4) User factors; & 4 & - & - & - \\
\hline \multicolumn{5}{|l|}{ Element 2: Medical evaluation procedure } \\
\hline $\begin{array}{l}\text { if employees can tolerate the physiological burden } \\
\text { associated with respirator use }\end{array}$ & - & - & 4 & - \\
\hline $\begin{array}{l}\text { An employee can report medical signs or symptoms } \\
\text { that are related to the ability to use a respirator }\end{array}$ & - & 4 & - & - \\
\hline $\begin{array}{l}\text { A physician or other licensed health care } \\
\text { professional, supervisor, or the respirator program } \\
\text { administrator have informed the employer that an } \\
\text { employee needs to be reevaluated }\end{array}$ & - & 4 & - & - \\
\hline $\begin{array}{l}\text { Information from the respiratory protection program, } \\
\text { including observations made during fit testing and } \\
\text { program evaluation, indicates a need for employee } \\
\text { reevaluation }\end{array}$ & 4 & - & - & - \\
\hline $\begin{array}{l}\text { A change occurs in workplace conditions (physical } \\
\text { work effort, protective clothing, and temperature) } \\
\text { that may result in a substantial increase in the } \\
\text { physiological burden placed on an employee }\end{array}$ & 3 & 1 & - & - \\
\hline \multicolumn{5}{|l|}{ Element 3: Fit testing procedure } \\
\hline $\begin{array}{l}\text { The procedures may vary slightly from one } \\
\text { respirator to another due to differences in } \\
\text { construction and design }\end{array}$ & 4 & - & - & - \\
\hline
\end{tabular}




\begin{tabular}{|c|c|c|c|c|}
\hline Elements \& Sub & $\begin{array}{c}\text { Not } \\
\text { implemented }\end{array}$ & $\begin{array}{c}\text { Partially } \\
\text { implemented }\end{array}$ & $\begin{array}{c}\text { Fully } \\
\text { implemented }\end{array}$ & $\begin{array}{c}\text { Not } \\
\text { applicable }\end{array}$ \\
\hline $\begin{array}{l}\text { User seal check : to determine if the respirator is } \\
\text { properly adjusted to the face }\end{array}$ & 4 & 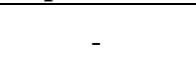 & 2. & - \\
\hline $\begin{array}{l}\text { Tight-fitting face piece must not be worn if facial } \\
\text { hair comes between the sealing periphery of the face } \\
\text { piece and the face or if facial hair interferes with } \\
\text { valve function }\end{array}$ & 4 & - & - & - \\
\hline $\begin{array}{l}\text { Respirators equipped with loose-fitting hoods or } \\
\text { helmets are acceptable with interfering facial hair }\end{array}$ & 4 & - & - & - \\
\hline Qualitative fit testing (QLFT) & 4 & - & - & - \\
\hline Positive pressure fit check & 4 & - & - & - \\
\hline Negative pressure fit check & 4 & - & - & - \\
\hline Qualitative Fit Testing & 4 & - & - & - \\
\hline \multicolumn{5}{|l|}{ Element 4: Proper respirator use } \\
\hline Contaminant related factors & 2 & 2 & - & - \\
\hline Task related factors & 2 & 2 & - & - \\
\hline Operator related factors & 2 & 2 & - & - \\
\hline \multicolumn{5}{|l|}{$\begin{array}{l}\text { Element 5: Cleaning, disinfecting, storing, inspecting, } \\
\text { repairing and discarding }\end{array}$} \\
\hline \multicolumn{5}{|l|}{ Cleaning and disinfecting } \\
\hline $\begin{array}{l}\text { Respirators that may be worn by different } \\
\text { individuals must be cleaned and disinfected } \\
\text { before being worn by a different individual }\end{array}$ & - & 4 & - & - \\
\hline $\begin{array}{l}\text { The recommended immersion time is two } \\
\text { minutes }\end{array}$ & 4 & - & - & - \\
\hline \multicolumn{5}{|l|}{$\begin{array}{l}\text { Inspection } \\
\text { Must be inspected immediately prior to each } \\
\text { use }\end{array}$} \\
\hline $\begin{array}{l}\text { a. Emergency and rescue use respirators: } \\
\text { monthly }\end{array}$ & 2 & 2 & - & - \\
\hline $\begin{array}{l}\text { b. Emergency escape-only respirators: before } \\
\text { being carried into the workplace for use } \\
\text { Items inspected }\end{array}$ & 2 & 2 & - & - \\
\hline $\begin{array}{l}\text { a. check for tightness of connections } \\
\text { b. condition of the respiratory inlet covering, } \\
\text { head harness, valves, connecting tubes, }\end{array}$ & 4 & - & - & - \\
\hline $\begin{array}{l}\text { harness assemblies, hoses, filters, } \\
\text { cartridges, canisters, end-of-service-life } \\
\text { indicator, electrical components, and } \\
\text { shelf-life date(s) }\end{array}$ & 4 & - & - & - \\
\hline $\begin{array}{l}\text { c. check for proper function of the } \\
\text { regulators, alarms, and other warning } \\
\text { system }\end{array}$ & - & - & - & 4 \\
\hline \multicolumn{5}{|l|}{ Repair } \\
\hline $\begin{array}{l}\text { Should be done only by personnel with adequate } \\
\text { training in the proper maintenance and assembly of } \\
\text { the respirators }\end{array}$ & 4 & - & - & - \\
\hline $\begin{array}{l}\text { Replacement parts must be only those designated for } \\
\text { the specific respirator being repaired }\end{array}$ & 4 & - & - & - \\
\hline \multicolumn{5}{|l|}{ Storage } \\
\hline $\begin{array}{l}\text { Storage locations are protected from contamination, } \\
\text { distortion, and damage } \\
\text { emergency and rescue use respirators must be }\end{array}$ & 2 & 2 & - & - \\
\hline $\begin{array}{l}\text { readily accessible and location must be clearly } \\
\text { marked }\end{array}$ & 2 & 2 & - & - \\
\hline \multicolumn{5}{|l|}{$\begin{array}{l}\text { Element 6: Procedures to ensure adequate air quality, } \\
\text { quantity and flow of breathing air for SAR (Supplied } \\
\text { Air Respirator) }\end{array}$} \\
\hline $\begin{array}{l}\text { Oxygen must meet the requirements of the United } \\
\text { States Pharmacopoeia for medical or breathing } \\
\text { oxygen }\end{array}$ & - & 2 & - & 2 \\
\hline $\begin{array}{l}\text { Compressed gaseous air must meet the requirements } \\
\text { for grade D as described in CGA G-7.1-1997 }\end{array}$ & - & 2 & - & 2 \\
\hline The moisture content of the cylinder air must not & 2 & - & - & 2 \\
\hline
\end{tabular}




\begin{tabular}{|c|c|c|c|c|}
\hline Elements \& Sub & $\begin{array}{c}\text { Not } \\
\text { implemented }\end{array}$ & $\begin{array}{c}\text { Partially } \\
\text { implemented }\end{array}$ & $\begin{array}{c}\text { Fully } \\
\text { implemented }\end{array}$ & $\begin{array}{c}\text { Not } \\
\text { applicable }\end{array}$ \\
\hline $\begin{array}{l}\text { exceed a dew point of }-50 \mathrm{~F}(-45.6 \mathrm{C}) \text { at one } \\
\text { atmosphere pressure }\end{array}$ & & & & \\
\hline $\begin{array}{l}\text { When compressors are used to supply breathing air, } \\
\text { the moisture content must be controlled so that the } \\
\text { dew point at one atmosphere pressure is } 10 \mathrm{~F}(5.56 \\
\text { C) below the ambient temperature }\end{array}$ & 2 & - & - & - \\
\hline $\begin{array}{l}\text { Sorbent beds and filters that are used to ensure the } \\
\text { air quality must be maintained and replaced or } \\
\text { refurbished periodically following the } \\
\text { manufacturer's instructions }\end{array}$ & 2 & - & - & - \\
\hline \multicolumn{5}{|l|}{ Element 7: Training } \\
\hline \multicolumn{5}{|l|}{ Must be able to demonstrate knowledge of: } \\
\hline $\begin{array}{l}\text { Why the respirator is necessary and how improper } \\
\text { fit, usage, or maintenance can compromise the } \\
\text { protective effect of the respirator }\end{array}$ & - & - & 4 & - \\
\hline $\begin{array}{l}\text { What the limitations and capabilities of the } \\
\text { respirator are }\end{array}$ & - & - & 4 & - \\
\hline $\begin{array}{l}\text { How to use the respirator effectively in emergency } \\
\text { situations including situations in which the respirator } \\
\text { malfunctions }\end{array}$ & - & - & 4 & - \\
\hline $\begin{array}{l}\text { How to inspect, put on and remove, use, and check } \\
\text { the seals of the respirator }\end{array}$ & - & - & 4 & - \\
\hline $\begin{array}{l}\text { What the procedures are for maintenance and } \\
\text { storage of the respirator }\end{array}$ & - & - & 4 & - \\
\hline $\begin{array}{l}\text { How to recognize medical signs and symptoms that } \\
\text { may limit or prevent the effective use of respirators }\end{array}$ & 4 & - & - & - \\
\hline $\begin{array}{l}\text { The general requirements of the OSHA respiratory } \\
\text { protection standard }\end{array}$ & 4 & - & - & - \\
\hline \multicolumn{5}{|l|}{ Re-training, annually or when: } \\
\hline $\begin{array}{l}\text { Changes in workplace / respirator type make the } \\
\text { previous training obsolete }\end{array}$ & - & - & - & 4 \\
\hline $\begin{array}{l}\text { Inadequacies in the employee's knowledge or use of } \\
\text { the respirator indicate that the employee has not } \\
\text { retained the required level of understanding or skill }\end{array}$ & 4 & - & - & - \\
\hline $\begin{array}{l}\text { any other situation arises in which retraining appears } \\
\text { necessary to ensure safe respirator use }\end{array}$ & 4 & - & - & - \\
\hline \multicolumn{5}{|l|}{ Element 8: Program Evaluation } \\
\hline $\begin{array}{l}\text { Program evaluations must be performed periodically } \\
\text { It is recommended that the evaluation be conducted }\end{array}$ & 4 & - & - & - \\
\hline $\begin{array}{l}\text { It is recommended that the evaluation be conducted } \\
\text { by a knowledgeable person not directly associated } \\
\text { with the program instead of the respiratory } \\
\text { protection program administrator }\end{array}$ & 4 & - & - & - \\
\hline $\begin{array}{l}\text { The outside individual brings a new set of eyes in an } \\
\text { attempt to prevent overlooking deficiencies }\end{array}$ & 4 & - & - & - \\
\hline
\end{tabular}

\section{Discussion}

Health Risk Assessment (HRA) is a way of gathering information that describes the magnitude of the potential consequences of a hazardous event and the likelihood that these consequences will occur. Health Risk Assessment (HRA) is the main media for implementing occupational health risk management including identification, assessment, and recommendations for preventive measures as required by article 4 letter a of Government Regulations' the Republic of Indonesia Number 88 year of 2019 concerning Occupational Health. ${ }^{17}$ HRA is conducted using three levels of assessment that direct and prioritize ongoing risk assessments and subsequent risk control for areas that constitute the highest risk to health over the course of employment. Health risk assessment is carried out by considering acute and chronic exposures, including: (1) 
Determining consequences; (2) Determining possible exposure; and (3) Determining risk classes by applying consequences and probability to the risk analysis matrix.Health Risk Assessment is needed to avoid or reduce levels of exposure, as an initial step in developing an occupational health program. HRA serves as a medium for finding and recognizing all hazards in the workplace, identifying risk groups, and assessing health problems due to exposure. ${ }^{18}$

Similar Exposure Group (SEG) is a group of workers who have a similar general exposure profile because they have similarities in working frequency, use of materials and processes in doing a job. One of the reasons for not diagnosing Occupational Diseases is due to the non-objective assessment of health risks and the history of exposure which is only obtained from the history. The results of the occupational health risk history taking can be objective, subjective and intersubjective. Therefore it is necessary to assess the risk with the level of exposure to each worker. Team involvement is required as part of the management of occupational diseases in the Company. After an assessment of the risks and their exposures to workers, it is then possible to determine the groups of workers who work in certain places and jobs with the same type of health risk exposure. ${ }^{1}$

Based on existing risk control in Health Risk Assessment (HRA), efforts to control occupational health risks at production unit PT. X tin smelter still needs to be improved to reduce the risk of exposure to health factors in the workplace. The implementation of Occupational Health Services (PKK) as stipulated, which can refer to the Regulation of Manpower Minister Republic of Indonesia number 3 year of 1982 must be implemented properly in relation to efforts to prevent and promote occupational health due to the high potential occupational health hazards from the tin smelter production activities of PT. X. ${ }^{19}$ This of course must be followed by a strong commitment from the company management to provide facilities, personnel, budget and implementation of occupational health programs in order to successfully implement Occupational Disease Management at production unit PT. X tin smelter. ${ }^{20}$ Related programs with Industrial Hygiene management that must be carried out are implementing the OHS work environment requirements as stipulated in the Minister of Manpower Regulation Number 5 of 2018, including measuring and controlling the Work Environment periodically at least annually. ${ }^{21}$ Likewise with the Periodic Workforce Health Examination program, it must be carried out by employers at least once a year as stated in the Regulation of Manpower Minister Republic of Indonesia number 2 year of 1980, with examination items referring to the results of the Health Risk Assessment (HRA) which is further outlined in workforce health examination guidance documents. ${ }^{22}$

Occupational respiratory hazard or risk factors come from raw materials, by-products, production processes, products or waste. Respiratory hazard can be in the form of dust / particulates, gas, vapor or fume, in the form of organic or inorganic materials, of natural or artificial origin, such as the earth's crust, plants, animals, natural or man made fibers (MMF). 
Workers are exposed through inhalation of air at work. If these risk factors are not controlled, Pulmonary Diseases (Occupational Diseases) will be high and the symptoms from mild coughing to serious shortness of breath. Companies can suffer losses due to decreased worker productivity and even risk losing reliable workers. ${ }^{23}$ Generally, chemical contaminants in the workplace air can be classified into two, that is gases and vapors and particulates in the air or aerosols. The gas and vapor groups can be further subclassified into gases and vapors respectively. Particulate or often called aerosol, basically can be subclassified into solid aerosol and liquid aerosol. Solid aerosols can be in the form of dust (dust), fiber, smoke (smoke) and fume. Liquid aerosols can be mist and fog. ${ }^{24}$ Suma'mur stated that stannosis had no massive fibrosis, no signs of pulmonary defects, complications rarely occurred, and at the initial stage of illness, X-rays of the lungs showed increased hue and enlargement of the hilar, then nodules appeared in the area between the third ribs. Initially at right lung then left lung, further addition of complexion is lost, while nodules are more pronounced and of high density. ${ }^{25}$

Respiratory Protection Program (RPP) is a occupational health program especially in reducing the incidence of occupational respiratory diseases. In terms of regulation, RPP can be linked to fulfilling the OHS requirements for Personal Protective Equipment Management as in the Regulation of Manpower Minister Republic of Indonesia Number 8 year of 2010 concerning Personal Protective Equipment. ${ }^{26}$ The respiratory protection program (RPP) is intended to protect employees from exposure to hazardous levels of work dust, fumes, mist, gases, vapors, biological agents and infectious pathogens. ${ }^{27}$ RPP in the workplace consists of several elements. The following are some of the RPP standards for application in the workplace: (1) Elements of the Occupational Safety and Health Administration RPP (OSHA-29 CFR 1910.134) ${ }^{28}$; (2) Elements of the National Safety Council (NSC) 2002 RPP $^{29}$; (3) Elements of RPP from the Kolahi study, Hadi et. al. 2016 at 24 Petrochemical Plants ${ }^{14}$;(4) Elements of RPP from Prof.'s study. Dr. dr. Meily Kurniawidjaja M.S., Sp.Ok. year $2010{ }^{2}$

The most important component of the RPP is the selection of a respirator, as it contains a key element of respiratory hazard identification. Respiratory hazard identification includes analysis of current or future work processes that may require respiratory protection. Analysis can be completed in several ways. An industrial hygienist can carry out an evaluation which ideally includes monitoring the actual exposure of the personnel performing the work. ${ }^{13}$ Respirator selection depends on the potential respiratory hazard in the work area. There are two conditions that have potential dangers to breathing, namely the IDLH (Immediately Dangerous to life or Health) state and Non-IDLH. IDHL conditions include gaseous contaminants, vapors, and oxygen deficiency. Meanwhile, Non-IDLH includes gaseous, vapor, and particulate contaminants. In addition, there are three factors that are important in selecting a respirator, namely, the type of contaminants, the type of work or task, and the character of the operator itself. Given the 
differences in potential hazards in the work area, a good understanding is needed to determine the type of respirator in order to work effectively.

Medical evaluation is needed to ensure that workers who will use the respirator are allowed and physically ready to work on the respirator. This evaluation is carried out before workers perform fit testing and use a respirator where workers must also have a written recommendation from a doctor.The RPP should include a process for cleaning and disinfecting respiratory PPE. If respiratory PPE is used for one employee, it should be cleaned and disinfected as often as needed. Likewise, for respiratory PPE used by more than one employee, the respiratory PPE must be cleaned and disinfected before use. Respiratory PPE used in emergencies, testing or training, should also be cleaned and disinfected after use. When storing respiratory PPE, it must be protected against contamination, dust, sunlight, humidity, temperature and extreme deformation. ${ }^{27}$

After being informed that they are medically capable of wearing a respirator, workers should be tested for conformity with the appropriate make, model and size of the respirator. The fit testing aims to test the suitability between the face covering of the respirator and the face of the worker. It takes about fifteen to twenty minutes to complete the fit testing and is evaluated at least once a year. There are two types of conformity tests: qualitative and quantitative. The qualitative suitability test is a pass / fail test method that uses a sense of taste or smell, or a worker's reaction to an irritant to detect leaks in a respirator. Qualitative conformity testing does not measure the true number of leaks. This test is based solely on the worker detecting a leak of the test material into the respirator. Qualitative suitability testing is typically used for half or half-mask respirators that cover only the mouth and nose. Meanwhile, quantitative suitability testing uses a machine or instrument to measure the actual amount of leakage to the face covering and does not depend on senses of taste, smell, or irritation. Observation data suggest opportunities to reduce the risk of Pulmonary Pulmonary Disease including strap placement, checking the user's seal, and reusing the disposable N95-filter facepiece respirator. ${ }^{30}$

Every Respiratory Protection Program (RPP) implementation must hold a comprehensive training of every respiratory PPE user. Based on the research of Honarbakhsh and colleagues, health workers who have positive perceptions and a moderate level of knowledge and practice about the use of respiratory PPE, fully implementing the respiratory protection program in the hospital will be very helpful in increasing the knowledge, perceptions and practices of health workers about respiratory PPE. ${ }^{31}$

Workers should be aware that respiratory PPE does not eliminate hazards. If the respiratory apparatus or respiratory PPE fails, the worker will be exposed to hazardous substances. Therefore, minimize the possibility of failure, respiratory PPE must be properly installed and maintained in a clean and usable condition. On the RPP training, some important topics must be explained including: why respiratory PPE is used, the nature of respiratory hazard, the consequences of 
respiratory PPE if it is not "fit" or not suitable, the ability and limitations of respiratory PPE, cleaning and storing respiratory PPE, how to use respiratory PPE in an emergency, how to recognize medical signs and symptoms that may limit the effectiveness of use of respiratory PPE, as well as regulations regarding respiratory PPE. ${ }^{32}$

\section{Conclusion}

It is known that several elements of the RPP have not been fully implemented, some of it: (1) compliance with respirator standards, (2) absence of a respirator selection procedure, (3) absence of protective clothing, (4) absence of conformity test implementation, (5) management improper cleaning and inspection, and (6) no evaluation of respirator use. In addition, specific work processes that require Supplied Air Respirators (SAR) have not been anticipated, improving training materials, periodic training schedules and evaluation of lesson plans need to be considered.

To encourage the implementation of RPP, significant effort is required for all components, especially fit testing and employee evaluation. Suggestions from this research are to employers, managers and $\mathrm{OSH}$ professionals in companies to compile documents and procedures for the Respiratory Protection Program as standard and to improve the elements of the Respiratory Protection Program that have not been fulfilled. In addition, to the government, academics and the public to participate in continuous coaching, supervision, examination and evaluation related to the Respiratory Protection Program.

\section{Acknowledgement}

Acknowledgment for OHS Department Public Health Faculty University of Indonesia and Provincial Government of the Bangka Belitung Islands who have supported this research.

\section{Funding}

This research was not funded by any party.

\section{Conflict of Interest}

The authors declare that have no conflict of interest in this study.

\section{References}

1. Kurniawidjaja LM, Ramdhan DH. Penyakit Akibat Kerja Dan Surveilans. UI Publishing; 2019.

2. Kurniawidjaja LM. Program Perlindungan Kesehatan Respirasi di Tempat Kerja Manajemen Risiko Penyakit Paru Akibat Kerja. J Respirologi Indones. 2010;30(4):217-229.

3. HSE. Occupational Lung Disease in Great Britain. Published online 2018. 
4. WHO. Early Detection of Occupational Diseases.; 1986.

5. Peraturan Presiden Nomor 7 Tahun 2019 Tentang Penyakit Akibat Kerja.

6. Suharyanto A, Sulistiyono E, Firdiyono F. Dissolution of Tin Slag Bangka Using $\mathrm{NaOH}$ Solution. Maj Metal. 2014;V(29.3):7.

7. Saleh N, Rodliyah I, Rochani S. Eliminasi Senyawa Silika dari Terak Peleburan Timah Menggunakan Asam Fluoro-Silikat. Teknol Miner dan Batubara. 2015;11(4):107-117.

8. Karalezlİ A. Stannosis Occurred by Tin Plating : Case Report. Published online 2009:163-166.

9. Soedirman, Prawirakusumah S. Kesehatan Kerja Dalam Perspektif Hiperkes \& Keselamatan Kerja. Penerbit Erlangga; 2014.

10. Dicken DY, Scott MJ. An Investigation into Health Conditions in a Tin Smelter with special reference to Stannosis. Med J Malaya. 1961;16(1):1-13. https://www.cabdirect.org/cabdirect/abstract/19622703573

11. Rui, Wang (Kunming Metallurgy Hospital of Occup.Diseases, Renmin-dong Rd., Kunming, 650216 C. ANALYSIS OF 117 CASES OF STANNOSIS. Ind Heal Occup OISEASES. 1994;(R135.2). http://en.cnki.com.cn/Article_en/CJFDTotal-GYWZ406.008.htm

12. Honarbakhsh M, Jahangiri M, Ghaem H, Farhadi P. Respiratory Protection Program Compliance in Iranian Hospitals: Application of Fuzzy Analytical Hierarchy Process. Work Heal Saf. 2018;66(4):173-182. doi:10.1177/2165079917703410

13. Ryan MPH, RN, COHN-S MG. Developing a respiratory protection program: Understanding the written elements. AAOHN J. 2001;49(6):293-309. https://search.proquest.com/docview/219359454?accountid=17242

14. Kolahi H, Jahangiri M, Ghaem H, et al. Evaluation of Respiratory Protection Program in Petrochemical Industries: Application of Analytic Hierarchy Process. Saf Health Work. 2018;9(1):95-100. doi:10.1016/j.shaw.2017.05.003

15. Cantino V, Vincentiis P De, Racca G. Handbook Risk Management Guidelines Companion to AS/NZS 4360:2004. Vol 51. Jointly published by Standards Australia International Ltd and Standards New Zealand; 2016.

16. Ramli S. Pedoman Praktis Manajemen Risiko Dalam Perspektif K3 OHS Risk Management. PT. Dian Rakyat; 2010.

17. Peraturan Pemerintah Nomor 88 Tahun 2019 Tentang Kesehatan Kerja.

18. Kurniawidjaja, Meily. Martomulyono, Suharnyoto. Susilowati IH. Teori Dan Aplikasi Promosi Kesehatan Di Tempat Kerja Meningkatkan Produktivitas. Universitas Indonesia Publishing; 2020.

19. Peraturan Menteri Tenaga Kerja Nomor 3 Tahun 1982 Tentang Pelayanan Kesehatan Kerja.

20. Peraturan Pemerintah Nomor 50 Tahun 2012 Tentang Penerapan Sistem Manajemen Keselamatan Dan Kesehatan Kerja. 
21. Peraturan Menteri Ketenagakerjaan Nomor 5 Tahun 2018 Tentang K3 Lingkungan Kerja.

22. Kementerian Ketenagakerjaan RI. Himpunan Peraturan Kesehatan Kerja.; 2010.

23. Kurniawidjaja LM. Teori Dan Aplikasi Kesehatan Kerja. UI Publishing; 2010.

24. Lestari F. Bahaya Kimia: Sampling \& Pengukuran Kontaminan Kimia Di Udara. Penerbit Buku Kedokteran EGC; 2009.

25. PK S. Higene Perusahaan Dan Kesehatan Kerja. 2nd ed. PT. Gunung Agung; 1976.

26. Peraturan Menteri Tenaga Kerja Dan Transmigrasi R.I. Nomor PER.08/MEN/VII/2010 Tentang Alat Pelindung Diri.

27. Shirley M. Respiratory Protection Simplified. Sch Journals. 2011;56:55-57.

28. OSHA. OSHA-29 CFR 1910.134 Respiratory Protection Program Guidelines. Accessed June 24, 2020. https://www.osha.gov/enforcement/directives/cpl-02-02-054

29. Plog BA, Quinland PJ. Fundamentals of Industrial Hygiene. 5th ed.; 2002. doi:10.1097/00043764-197201000-00011

30. Bien EA, Gillespie GL, Betcher CA, Thrasher TL, Mingerink DR. Respiratory Protection Toolkit: Providing Guidance Without Changing Requirements-Can We Make an Impact? Workplace Health Saf. 2016;64(12):596-602. doi:10.1177/2165079916657831

31. Honarbakhsh M, Jahangiri M, Ghaem H. Knowledge, perceptions and practices of healthcare workers regarding the use of respiratory protection equipment at Iran hospitals. J Infect Prev. 2018;19(1):29-36. doi:10.1177/1757177417724880

32. Prilyana Fajria I, Al. E. Respiratory Protection Program: Assessment and Use. Monthly Newsletter Indonesian Industrial Hygiene Association. 2020. 